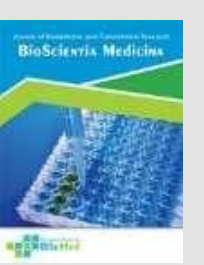

Bioscientia Medicina: Journal of Biomedicine \& Translational Research

Journal Homepage: www.bioscmed.com

\title{
The Effect of the Covid-19 Pandemic on Increased Anxiety of Cancer Survivors of Wijayakusuma Group
}

\section{Ian Oscar Prima ${ }^{\star}$, Darwito ${ }^{2}$}

${ }^{1}$ Resident of General Surgery, Faculty of Medicine Diponegoro University, Semarang, Indonesia

${ }^{2}$ Department of Surgery, Faculty of Medicine Diponegoro University, Semarang, Indonesia

\author{
A R T I C L E I N F O \\ Keywords: \\ COVID-19 \\ Anxiety \\ Breast cancer \\ General anxiety disorder \\ Descriptive study
}

\section{*Corresponding author: \\ Ian Oscar Prima \\ E-mail address: \\ dr.ianoscar77@gmail.com}

All authors have reviewed and approved the final version of the manuscript.

https://doi.org/10.37275/bsm.v6i4.488

\begin{abstract}
A B S T R A C T
Background. Corona Virus Disease-19 (COVID-19) is an infectious disease caused by the SARS-CoV2 virus. The increasing number of COVID-19 cases have caused anxiety problems in several countries. Breast cancer patients already have anxiety about their own disease. During the COVID-19 pandemic, this anxiety might be increased due to the fear of getting infected both in the environment where they live or in the hospital. Methods: This is a descriptive observative study, on females with history of cancer in the Wijayakusuma group, Dr. Kariadi Hospital, Semarang, Central Java during February - March 2021. Data collected using questionnaire based on Generalized Anxiety Disorder 7-item (GAD-7) that the question was modified for evaluating anxiety about COVID-19 pandemic in breast cancer patients. Data analyzed using SPSS $23^{\text {rd }}$ version Results: In this study, the breast cancer patient who not anxious were $19.1 \%$, slightly anxious $35.5 \%$, moderate anxious $23.6 \%$, and severe anxious $21.8 \%$. $74,5 \%$ patients feel they must wash their hands more often. $60,9 \%$ were worried about possibility of contracting COVID-19 of their members, 49,1\% afraid of COVID-19, 50,9\% were not afraid about COVID-19, 44,5\% feel uncomfortable when think about COVID-19, and 40,9\% Feel that COVID-19 is life-threatening. Conclusion: There was increase of anxiety level. There was a behavioral change in patients where patients wash their hands more often due to the COVID-19 pandemic.
\end{abstract}

\section{Introduction}

Corona Virus Disease-19 (COVID-19) is an infectious disease caused by the SARS-CoV2 virus or Corona Virus. According to Harahap, the Corona virus is zoonotic which can be transmitted from animals to humans, but some evidence has found that the virus can be transmitted from humans to humans through droplets, contact with droplets and even through transmission, especially this new type of Corona virus, namely Severe Acute Respiratory Syndrome Coronavirus-2 (SARS-CoV-2). ${ }^{1}$

According to data from the World Health
Organization (WHO), as of March 4, 2021, it is known that the spread of COVID-19 cases worldwide has reached 119,030,459 deaths, reaching 2,640,349, of which 13,884,338 cases occurred in Southeast Asia. In Indonesia, the spread of COVID-19 has reached $1,414,741$ cases with 38,329 deaths. ${ }^{2}$

The increasing number of COVID-19 cases, both new cases and those that cause death, have create and cause anxiety problems in several countries. As said by Lin (2020), with the increasing incidence of COVID-19, there is also increase of anxiety and fear as it is human 
nature because human care about their health and do not want faced death because of the infection. ${ }^{3}$ However, it should be noted that fear can also lead to misperceptions in society.

Miranda et al., said that the pandemic can impact the mental health of children and adults in several ways. A pessimistic view of a pandemic, for example fear of getting infected or infecting other family can have an impact on behavior change. On the other hand, being optimistic about the pandemic and not worrying about the infection can result in lower rates of depression. ${ }^{4}$

For breast cancer patients, they already have anxiety about their own disease. It is said, breast cancer patients often experience psychotic disorders in the form of initial anxiety when they undergo chemotherapy. ${ }^{5}$ Early-stage breast cancer is a common disease with an estimated 27,400 new cases diagnosed and caused $6.1 \%$ of deaths in Canada in 2010.6

Based on this explanation, it can be ascertained that breast cancer patients might already have a risk of the anxiety of their disease. During the COVID-19 pandemic, this anxiety might be increased due to the fear of getting infected both in the environment where they live and, in the hospital, where the possibility of being infected is higher than in other environments. Based on this reason, the author is interested in studying the impact of the COVID-19 pandemic on the increase of anxiety in cancer patients of the Wijayakusuma group.

\section{Methods}

This study is a descriptive observative study. The population of this study was all female patient with history of breast cancer in Wijayakusuma group, Dr. Kariadi Hospital, Semarang, Central Java during February - March 2021. The sample size was obtained by using the consecutive simple sampling method. Inclusion criteria were breast cancer patients that willing to be a research subject after being given an explanation previously and had a complete medical record accompanied by Anatomical Pathology lab results. Data collected using questionnaire based on Generalized Anxiety Disorder 7-item (GAD-7) that the question was modified for evaluating anxiety about COVID-19 pandemic in breast cancer patients. ${ }^{7}$ Data analyzed using SPSS 23.0 version. Before this research was carried out, the approval of the Health Research Ethics Commission of the Faculty of Medicine, Diponegoro University (Ref No. 838/EC/KEPKRSDK/2021).

\section{Results}

110 samples of patients with cancer history are taken from the medical records. We interviewed them and we collected data based on Generalized Anxiety Disorder 7-item (GAD-7) questionnaire. Distribution of anxiety levels of cancer patients in the Wijayakusuma group who are not anxious (score 0-4) are 21 people (19.1\%), slightly anxious (score 5-9) are 39 people (35.5\%), moderate anxious (10-14) 26 people $(23.6 \%)$, and severe anxious (>15) 24 people $(21.8 \%)$.

Table 1. Data of anxiety levels in Wijayakusuma group

\begin{tabular}{|l|c|c|}
\hline & Frequency & Percentage \\
\hline No Anxiety & 21 & 19.1 \\
\hline Mild Anxiety & 39 & 35.5 \\
\hline Moderate Anxiety & 26 & 23.6 \\
\hline Severe Anxiety & 24 & 21.8 \\
\hline Total & 110 & 100.0 \\
\hline
\end{tabular}

After filling out the questionnaire and assessing the anxiety level of each breast cancer patient in the Wijayakusuma group, we interviewed all samples to find out what gave each patient a sense of anxiety with open question. We found various reasons why they feel anxious about COVID-19, as listed in the following table: 
Table 2. Reasons patients were anxiety

\begin{tabular}{|l|c|c|}
\hline \multicolumn{1}{|c|}{ Reasons } & Frequency & Percentage \\
\hline Afraid with COVID-19 & 54 & 49,1 \\
\hline Worried to be Infected by COVID-19 & 67 & 60,9 \\
\hline Feel nervous or anxious when watching news about COVID-19 & 34 & 30,9 \\
\hline Feel uncomfortable when think about COVID-19 & 49 & 44,5 \\
\hline Feel uncomfortable that they must wash their hands more often & 82 & 74,5 \\
\hline Feel that COVID-19 is life-threatening & 45 & 40,9 \\
\hline COVID-19 made the patient restless & 9 & 8,2 \\
\hline Palpitations when think about COVID-19 & 18 & 16,4 \\
\hline $\begin{array}{l}\text { Afraid to meet their friends and family for fear of contracting COVID- } \\
19\end{array}$ & 40 & 36,4 \\
\hline
\end{tabular}

\section{Discussion}

Anxiety is an unpleasant emotional condition that comes from within associated with a threat of unknown origin by the individual. These feelings are accompanied by somatic, physiological, autonomic, biochemical, hormonal, and behavioral components. The main pathway of anxiety in cancer patients are the biopsychosocial causes. However, there are also direct neuropsychiatric effects of cancer or treatment even though precise estimation remains unknown. Some tumors released cytokine interleukine- 6 , antidiuretic hormone secretion in inappropriate amount, malignant hypercalcaemia that can induce anxiety and depression. COVID-19 increases anxiety in patients with cancer. Excessive anxiety in cancer patients can affect the patient's motivation in carrying out chemotherapy, thus affecting the chemotherapy treatment. $8-9$

This study was conducted on cancer patients in the Wijayakusuma group. In this study, the breast cancer patient who not anxious were $19.1 \%$, slightly anxious $35.5 \%$, moderate anxious $23.6 \%$, and severe anxious $21.8 \% .74,5 \%$ patients feel they must wash their hands more often. $60,9 \%$ were worried about possibility of contracting COVID-19 of their members, $49,1 \%$ afraid of COVID-19, 50,9\% were not afraid about COVID-19, $44,5 \%$ feel uncomfortable when think about COVID-19, and $40,9 \%$ Feel that COVID-19 is life-threatening. $30,9 \%$ patients feel nervous or anxious when watching news about COVID-19 and $36,4 \%$ patients afraid to meet their friends and family for fear of contracting COVID-19.

Anxiety is a part of human life characterized by feelings of fear or worry that are deep and ongoing. ${ }^{10}$ Anxiety can be influenced by various factors but depending on the maturity of one's personality, experience of challenges, self-esteem and coping mechanisms, self-defense mechanisms that varies in every human. ${ }^{11}$

This is in accordance with the research by Cona, et al. that stated that most patients $(52.6 \%)$ did not think that the pandemic affected treatment outcomes. Patients believe they are at a higher risk of contracting COVID-19 and therefore adhering to safety standards will help them feel more protected. Good relationships with health workers contribute to receiving care directly without causing anxiety for patients. ${ }^{12}$

The status of a global pandemic or epidemic indicates that the spread of COVID-19 is spreading very quickly. Several steps were taken by the government so that the corona virus did not spread quickly, such as implementing work from home (WFH), social distancing, and others. ${ }^{13}$ Knowledge of COVID-19 can reduce a person's level of anxiety. The society is educated to adopt a healthy lifestyle by washing hands with soap as often as possible, wearing masks when traveling out of the house, and keeping a distance. ${ }^{14-16}$

\section{Conclusion}

There was increase of anxiety level among cancer 
patients in the Wijayakusuma group due to the COVID19 pandemic. There is a behavioral change in patients where patients wash their hands more often for fear of COVID-19 infection.

\section{References}

1. Fitra M, Harahap W, Zulfiqara Y. Elective surgery service of oncology surgery division before and during early pandemic. Biomed $\mathrm{J}$ Indones. 2021; 19: 181-92.

2. World Health Organization (WHO). WHO Coronavirus (COVID-19) Dashboard. 2021. p. https://covid19.who.int/.

3. Kobayashi T, Jung, Linton N, Kinoshita R, Hayashi K. Communication the risk of Death from Novel Coronavirus Disease (COVID-19). J Clin Med. 2020; 9: 580.

4. Marques D, Miranda D, Athanasio S, Cecília A, Oliveira S, Simoes-e-silva AC. How is COVID19 pandemic impacting mental health of children and adolescents? Int J Disaster Risk Reduct. January, 2020.

5. Yudono DT. The effect of progressive muscle relaxation therapy on anxiety of patients with chemotherapy measures at Dadi Keluarga Hospital Banyumas. 2020; 20(Icch 2019): 548.

6. Brenner D., Weir H, Demers A, Ellison L. Projected estimates of cancer in Canada in 2020. CMAJ. 2020;199-205.

7. Spitzer RL, Kroenke K, Williams JB, Löwe B. A brief measure for assessing generalized anxiety disorder: the GAD-7. Arch Intern Med. 2006; 166: 1092-7.

8. Pitman, et al. Depression and anxiety in patients with cancer. Clinical Updates BMJUK. 2018.

9. Lutfa U, Maliya A. Factors Affecting Patient Anxiety in Chemotherapy Actions at Dr. Moewardi Hospital Surakarta. Nursing Science. 2018; 1(4): 113-29.
10. Nadeak RJ. Relationship between family support and anxiety level of preoperative patients in RB2 room of HAM Hospital. 2010. http://repository.usu.ac.id/.

11. Stuart GW. Psychiatric Nursing Pocket Book. Jakarta: EGC; 2007.

12. Cona MS, Dalu D, Ferrario S, Tosca N, Gambaro AR, Filipazzi V, et al. 1570P The emotional impact of COVID-19 outbreak on cancer out-patients and their caregivers: Impressions from the heart of the Italian pandemic. Ann Oncol. 2020 Sep; 31: S956-7.

13. Fitria L, Ifdil I. Adolescent anxiety during the Covid-19 pandemic. J Educ $\mathrm{J}$ Educator Indonesia. 2020; 6(1): 1.

14. Suprabowo GYA. The Meaning of Hospitality in the New Normal Era: A Theological Review Luke 10: 25-37. Harvest J Teol and Christian Leaders. 2020; 5(1): 43-58.

15. Pratiwi FI, Salamah L. Italy on COVID-19: response and strategy. J Glob Strategy. 2020; 14(2): 389.

16. Machendrawaty N, Yuliani Y, Setiawan AI, Yuningsih Y. Optimizing the function of mosques in the midst of the Covid 19 pandemic: Study of syar'i, regulations and applications. UIN Sunan Gunung Jati [Internet]. 2020; 19: 1-11. Available from: http://digilib.uinsgd.ac.id/30900/ 